Wilde put in much post-graduate work in London and Vienna, and on his return to Dublin founded St. Mark's Hospital. Not content with an enormous practice in ophthalmology and aural surgery, Wilde was responsible for the Census for many decades. $\mathrm{He}$ was a medical editor, he was a noted authority on Irish antiquities and towards the end of his career catastrophe overtook him in the shape of a prosecution in the Courts. It was an unsavoury business and although the plaintiff won her case and was awarded only a farthing's damages, it must have done incalculable harm to Wilde both professionally and socially.

Woven in with Wilde's life story are good accounts of the awful famine years in Ireland, the hungry forties, details of Swift's closing years, sidelights on Lever, and most of the revolutionaries in Ireland in the middle of last century, literature, art and poetry. We strongly advise all ophthalmic surgeons to read this book; in these worrying times, if they do, they will be sure of having a few days in which their minds can be switched off from present day realities to the delightful atmosphere of Ireland in the last century, and they will be thankful to the author, as the reviewer has been, for a rare treat.

\title{
CORRESPONDENCE
}

\section{THE NEEDS OF THE SERVICES}

\section{To the Editors of THE BRitish Journal of Ophthalmology.}

DEAR SIRS,-The interesting correspondence opened in your Journal of December, 1941, by Mr. Rugg Gunn, has been read by me with considerable concern because each writer, with the possible - exception of the initiator of the correspondence, seems to have over"looked one paramount fact-namely, that we must win this war and use every facility available to achieve this. This is certainly not the time for weighing up post-war consequences and withholding. our hand from this or that course because of later repercussions to our personal practices.

The second fact that seems to have been entirely overlooked by everyone is that conditions in Great Britain are not comparable with conditions overseas and especially in the battle areas. Here distances are immense and supplies very difficult at times.

Thirdly, we are almost in the fourth year of the war (or will be when this letter is published) and men who joined the Forces in 1939 are due for a second refraction in the immediate future. A number arrive overseas without glasses and many lose their glasses in action, so how can the bulk of refraction work in the Army be 
considered to be completed? It is just time to begin the work again.

Fourthly, as 70 per cent. of the Army ophthalmic work is refractions and as the amount of eye operative work undertaken is almost negligible at the present, and will remain so until a second front is formed, why not employ supervised opticians who are capable of doing refraction work when there are obviously insufficient ophthalmic surgeons to perform the large volume of this work promptly and thus prevent soldiers from being immobilised in Base Depots whilst awaiting refraction and glasses.

I had the privilege of , working with and observing the organisation of many Allied Ophthalmic Units in the Middle East for eighteen months and, without prejudice, I am certain that the staffing and organisation of the ophthalmic units of the Australian General Hospitals and Australian Optical Workshops are, for the purposes of this war and its winning, by far the most practical and efficient I have met. The refraction work is done well by opticians, the outpatient waiting list surprisingly low, the supply of spectacles speedy and reliable, and I attribute these facts to the discerning use of the services of trained and registered opticians, all under the surveillance of ophthalmic surgeons. There is one ophthalmic surgeon and one optician to each Australian General Hospital, with one Australian Optical' Workshop (staffed by two opticians under medical supervision) to approximately every two hospitals. It is not ideal and would not be contemplated in civil practice, but we are fighting a deadly war and every service must run efficiently and speedily. To suggest that the services of these opticians should be dispensed with (thus producing an obvious slowing-up of the eye service) in order to save the practices of ophthalmic surgeons after the war is beyond my conception and I simply reply that, if we lose this war, there will be no payable practices for any eye surgeons whatsoever, throughout the Empire.

I therefore submit the Australian system to your readers and leave for their consideration the excellent results of such a service.

\section{Yours faithfully,}

J. BRUCE HAMILTON, Major.

7th AUSTRALIAN GENERAL HOSPITAL, A.I.F., July 12, 1942.

\section{TWO CASES OF ORTHOPTIC INTEREST}

To the Editors of THE BRITISH JOURNAL OF OPHTHALMOLOGY.

DEAR SIRS, - With reference to the article entitled "Two Cases of Orthoptic Interest". by E. B. Alabaster, C. Rudd and M. Tree, which appeared in your last number, it appears that the two cases 